\title{
Promotion of academic scholarship and entrepreneurship through the writing and publishing of syllabi-based course textbooks for polytechnics in Ghana
}

\author{
Kutsanedzie, F. , Achio, S., Mensah, E. \\ Research and Innovation Centre, Accra Polytechnic, Accra, Ghana
}

Email address:

fkutsanedzie@apoly.edu.gh (Kutsanedzie, F.)

\section{To cite this article:}

Kutsanedzie, F., Achio, S., Mensah, E.. Promotion of Academic Scholarship and Entrepreneurship through the Writing and Publishing of Syllabi-Based Course Textbooks for Polytechnics in Ghana. Science Innovation. Vol. 2, No. 1, 2014, pp. 1-6.

doi: $10.11648 /$ j.si.20140201.11

\begin{abstract}
Quality education is the bedrock on which a country's developmental agenda rests. Its delivery requires several resources but importantly availability of trained staff and the requisite teaching materials needed to facilitate the impartation of knowledge. The study appraised three suggested projects namely: Project A, Subcontracting Printing of Textbooks; Project B, owing a Printing Press together with printing of Textbooks; Project $\mathrm{C}$, owing Printing Press and Bookshop together with Printing of Textbooks, on the need for writing of syllabi-based course textbooks by academics as a way of promoting scholarship through entrepreneurship using Accra Polytechnic in Ghana as a case study. Cost estimates used in the projects were done using the Ball pack Technique NPV method with selected discount factor of $28 \%$ and $32 \%$ were used rating the three projects in terms of viability and profitability. The analysis revealed that all the projects were viable and profitable as well as enhance promotion of research, scholarship among the academia, facilitate the delivery of quality education as well as income generation for staff and the Institution. Projects B, C and A ranked profitable in the order $1^{\text {st }}$ to $3^{\text {rd }}$ from the NPV analysis.
\end{abstract}

Keywords: Net Present Value, Syllabi-Based Course Textbooks, Projects, Research, Entrepreneurship, Profitability

\section{Introduction}

Education of the citizenry of a country is the lynched-pin on which the industrialization and development of a nation is linked. There is therefore the need for the educational institutions in a country to provide quality to its citizenry through the provision of up-to-date standard materials that would equip students, who would eventually offer the skilled man power for developmental take-offs with the necessary and needed contemporary knowledge and skills to withstand the competitive global challenge in various fields of endeavour.

Accra Polytechnic is one of the tertiary institutions in Ghana with the core mandate of training students to acquire technical and vocational skills to provide the needed middle man power to propel the country's developmental process. Sequel to this, syllabi have been developed and approved by National Accreditation Board of Ghana which are followed to provide tuition and training of students pursuing diverse programmes. The core mandate of Accra Polytechnic is to provide quality tuition to students. Oguntuase and Falaiye
(2004) revealed that the most effective way to mobilize people is through the provision of required information in the most useable form and that such information should be provided for the benefit of a large number of people. There is no doubt however that the target of the syllabi cannot be achieved without the provision of quality course books to help lecturers research and impart students with the information as prescribed by the syllabi as well as aid students understand and apply the lessons received. Popoola (1998) also revealed that the provision and efficient use of information resources are central to any meaningful research and teaching in Nigeria.

Year in year out, frontiers of knowledge are being expanded by the creation of knowledge pool which can be utilized to solve contemporary challenges the world is faced with. To provide quality education to students in order for them to keep abreast of current trends, there is the need to embrace contemporary innovations and technologies encapsulated in up-to-date books or materials. Nicholas and Rowlands (2008) found that students tend to economise by not purchasing the books that they have been recommended to read. Some students are also charged by their own 
University for coursepacks of research content. A study in the US found that sometimes the cost of these coursepacks rivals that of the textbooks, but they have no resale value to mitigate the cost (Baker 2007).

Study and teaching materials are the resources required by students for their study. They consists of recommended textbooks, books to support class texts, journals, past examination papers, reference books, monograph etc. while the research materials are used by higher degree students and lecturers. These are made up of periodicals, documents of different kinds, treaties, manuscripts, pamphlets, government publications conference proceedings and papers etc. (Fayose, 1995).

Lecturers employed to teach various courses are expected to have built expertise through their research works which should make them capable of writing course text books in their respective jurisdiction of service provision. These can be tailored to meet syllabi requirement, reviewed by expert reviewers, published, and then accepted and recommended as standard course textbooks or material by the Polytechnic in the delivery of standard quality education.

\subsection{Problem Statement}

In Accra Polytechnic, most lecturers compile handouts for the various taught courses which are sold to students as course materials. Since these handouts or materials are not peer reviewed and so their contents can be said not to be standardized. These are likely to contain mistakes and other anomalies. Some of these hand outs produced by the lecturers of the Polytechnics in Ghana fall into the public domain via students. It therefore makes it needful for the Institutions to find a way to aid the rewrite and upgrade of these materials into reviewed and publishable standards for approval and recommendation of the Institution as course based-textbooks for students, and promotion materials for their respective lecturers.

\subsection{Objectives of the Study}

The main import of this study is to help stem out handouts by aiding lecturers in the Institution to write course based-textbooks to be reviewed and published by the Institution to assure delivery of quality education to student; and to serve as promotion materials for lecturer, thus generating funds for lecturers and the Institution through the sales of published books.

\subsection{Justification for Study}

Every staff and student is a stake holder of the Institution. Information that would be put in the public domain by any staff will not affect the reputation of the that staff alone but would have either a positive or negative impact effect on the Institution as well as the entire staff and students. It therefore becomes prudent and necessary to regulate and standardize course materials that are sold to student which inevitably become public due to its mobility and transfer among students.

\section{Methodology}

\subsection{Charting of the Procedures and Processes Involved in the Publication of Syllabus - Based Course Textbooks}

The chart and procedures on which the study is based is shown in figure 1.

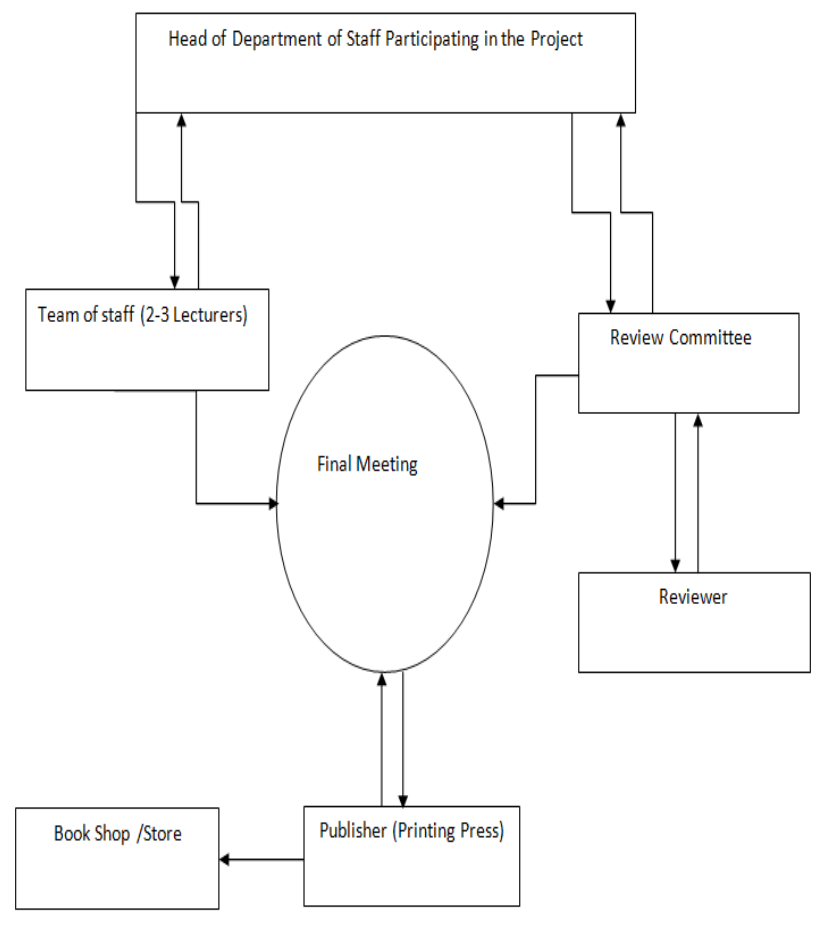

Figure 1. Project Organizational Chart

\subsection{Roles and Responsibilities for Involved in the Syllabus - Based Course Textbook Production Process}

\subsubsection{Head of Department of Participating Staff}

The Head of Department of the participating staff is to constitute a team of lecturers with expertise in a particular course to be mandated to come up with a draft syllabus based course textbook which is to be submitted within a given duration of $3-6$ months. Logistics needed are to be provided to the lecturers in order to deliver to the stated mandate.

\subsubsection{Team of Staff (Lecturers)}

Staff constituting a team can further do a breakdown of course into subtitles, for which they can share and write on. Each of them can write on the subtitles and later on come together to compile them. The team would consist of between 2-3 members with expertise in the course under consideration. They are expected to exhibit teamwork in preparing the draft copy by organizing series of brainstorming meetings and researches to come up with the needed facts. They are to compile all their written works together for the draft copy as well as do an internal peer reviewing of the constituents of the draft copy. The team would submit their draft copy to their respective Heads of Departments between a stipulated duration of 3-6 months. 


\subsubsection{The Review / Editorial Committee}

The draft work of the team submitted to their respective HODs would be forwarded to the editorial Review Committee as soon as received. The Review / Editorial Committee would be tasked to do internal editing and corrections, and then look for reviewers for the draft course book under consideration. This is to be done within a span of three weeks. The Committee is expected to give the duration of one month for the review.

\subsubsection{The Reviewer}

The reviewer is expected to be an expert in the course under consideration and an individual who has vast experience and has published a lot of materials in the field. An organization with high repute can be contracted to do such a review if need be. A reviewer is to deliver to his given mandate within the duration of one month.

\subsubsection{Final Book Copy Committee Meeting}

This would include the Management of the Institution, the Review/ Editorial Committee, the Team. It is at this meeting that everything about the book would be finalized. They are also to look for a publisher to do the printing depending on whether it is to be subcontracted or an internal press is to be used. The cost of the final book is also to be decided at this meeting.

\subsubsection{The Publisher}

The Publisher is the organization or press that would do the final printing when the drafts have been approved at the final meeting. The Publisher is to be given a duration of two weeks to deliver to that mandate.

\subsubsection{Bookshop / Store}

The printed books are to be delivered to a bookshop or store after the inspection of copies by members of the Final Book Copy Committee. The books would be sold and distributed at this point.

\subsection{Process Flow of Project}

The process would be initiated at the departmental level. The HODs (Heads of Departments) would have to form a 2-3 member teams with expertise in a named course taught within the department and mandate them to prepare a draft copy of a syllabus-based course textbook. Duration of 3-6 months would be given them to submit a draft copy of the book for onward submission to a Review / Editorial Committee for scrutiny, correction and subsequent submission to an Appointed Reviewer.

The Appointed Reviewer would be given one month to complete the review and return the copy with comments. The Review / Editorial Committee having received the reviewed copy from the Appointed Reviewer, would take note of the comments and then pass it on through the HODs to the Team. The Team would be given a month to do the necessary corrections as per the comments and resubmit the corrected work through their HODs to the Review / Editorial Committee who would in turn peruse and check thoroughly to ensure corrections are done accordingly.

After these checks have been done in accordance with the Appointed Reviewer's comments, the Final Book Committee Meeting would be organized to decide on the printing, the book cost and the Publisher to be appointed (if the printing would be subcontracted), or else approval given for the internal printing press to print copies to be presented to the Final Book Copy Committee Members before the mass printing is done. The publisher would then be given two weeks to deliver.

\subsection{Costs Estimation and Appraisal of Projects}

\subsubsection{Costs Estimation}

Ball pack estimate method was used in estimating the various cost estimates involved in the process in terms of printing and making of photocopies involved in the preplanning process; manpower requirements; building of press; bookshop; cost of equipment for the press summarized in tables below:

For the purpose of estimating cost involved in the process, an average of five (5) courses per department for fifteen (15) departments was considered. A total of Seven thousand (70000) book copies of averagely two hundred (200) page books are expected to be printed at the cost of Eight Ghana Cedis per book annually for Students within the Institution. This means a total of 70000 copies of books would be printed annually for an average of five courses per each department considering each of the three projects. The cost of typing a page is estimated at 0.50 Ghana Cedis. The estimated amount of One thousand Cedi (GH $\not 1000)$ per book is to be paid to a reviewer. A total of $\mathrm{GH} \notin 1,125$ is expected to be used in making photocopies of materials from writing to printing of the books. The cost of printing the total number of 70,000 book copies is higher for Project A $(\mathrm{GH} \phi 560,000)$ as compared to each of the two other projects $(\mathrm{GH} \propto 210,000)$ partly because it is expected to be subcontracted and the differentials $(\mathrm{GH} \notin 350,000)$ is the estimated cost to be paid to the subcontractors. The man power charges were estimated as the same for all the three projects while no building, and machinery and equipment cost was charged for Project A because the printing work is to be subcontracted. The difference in the building cost for Project B $(100,000)$ and Project (C) is that, the former is expected to be the cost of a building a print room whiles the latter a building a print and a bookshop.

Table 1. Estimated Costs for items

\begin{tabular}{lc}
\hline List of items & Cost GHc \\
\hline Building & 200000 \\
Machinery /Equipment & 700000 \\
Photo copies & 1125 \\
Printing of materials & 560000 \\
Manpower & 101000 \\
Total & 1562125 \\
\hline
\end{tabular}




\subsection{Cost Benefit-Analysis of Projects}

The appraisal was done using a cost discounted technique known as Net Present Value (NPV) for the three different projects considered: Project A, Subcontracting Printing of Textbooks; Project B, owing a Printing Press together with printing of Textbooks; Project C, owing Printing Press and Bookshop together with Printing of Textbooks. This was to enable the researchers compare and select the most profitable project. Two different discounting percentages of 24 and 28 were used because of the prevailing interest rate in
Ghana. According to Lin and Nagalingam (2000), Net present value (NPV) of a time series of cash flows, both incoming and outgoing, is defined as the sum of the present values (PVs) of the individual cash flows of the same entity. NPV compares the value of a dollar today to the value of that same dollar in the future, taking inflation and returns into account. If the NPV of a prospective project is positive, it should be accepted. However, if NPV is negative, the project should probably be rejected because cash flows will also be negative (INVESTOPEDIA, 2013)

Table 2. Cost Estimates Collected for the various Project under Consideration

\begin{tabular}{|c|c|c|c|c|c|c|}
\hline \multirow[t]{2}{*}{ Items } & \multicolumn{2}{|c|}{$\begin{array}{c}\text { Project A } \\
\text { Cost }\end{array}$} & \multicolumn{2}{|c|}{$\begin{array}{c}\text { Project B } \\
\text { Cost }\end{array}$} & \multicolumn{2}{|c|}{$\begin{array}{c}\text { Project C } \\
\text { Cost }\end{array}$} \\
\hline & GHe & US \$ & GH & US \$ & GH & US \$ \\
\hline photocopies & 1125 & & 1125 & & 1125 & \\
\hline Printing of materials & 560000 & & 210000 & & 210000 & \\
\hline Manpower & 101000 & & 101000 & & 101000 & \\
\hline Building & - & & 100000 & & 200000 & \\
\hline Machinery /Equipment & & & 700000 & & 700000 & \\
\hline Total & 662125 & & 1112125 & & 1212125 & \\
\hline
\end{tabular}

\section{Results and Discussion}

The cost collected for each of the projects was appraised using the Net Present Value (NPV) technique at a discount factor of $28 \%$ and $32 \%$ respectively for each of the three Projects $-\mathrm{A}, \mathrm{B}$ and $\mathrm{C}$. The results for the projects discounted at $28 \%$ are summarized in tables 3,4 and 5 respectively for Projects A, B and C. The NPVs of the three projects at $28 \%$ were A (654796.64), B (1072180.83) and C (994055.82) as shown in tables 3, 4 and 5 respectively. These show that the Project $\mathrm{B}$ is the most viable, and Project $\mathrm{C}$ is the least viable on the basis of their NPVs at $28 \%$ (NPV of B $>C>A$ ).

Table 3. Project A Cash Flows Discounted at 28\%

\begin{tabular}{|c|c|c|c|c|c|}
\hline Years & Cash outflow & Cash inflow & Cash flow & Discounting Factor $(1+i)^{\wedge}-n$ & Present Value (PV) \\
\hline 1 & 6621,25 & 840000 & 177875 & 0.78125 & 138964.8438 \\
\hline 2 & 560000 & 840000 & 280000 & 0.610351563 & 170898.4375 \\
\hline 3 & 560000 & 840000 & 280000 & 0.476837158 & 133514.4043 \\
\hline 4 & 662125 & 840000 & 177875 & 0.37252903 & 66263.60118 \\
\hline 5 & 560000 & 840000 & 280000 & 0.291038305 & 81490.72528 \\
\hline \multirow[t]{2}{*}{6} & 560000 & 840000 & 280000 & 0.227373675 & 63664.62912 \\
\hline & & & & NPV & 654796.6411 \\
\hline
\end{tabular}

Table 4. Project B Cash Flows Discounted at 28\%

\begin{tabular}{|c|c|c|c|c|c|}
\hline Years & Cash outflow & Cash inflow & Cash flow & Discounting Factor $(1+i)^{\wedge}-n$ & Present Value (PV) \\
\hline 1 & 1112125 & 840000 & -272125 & 0.78125 & -212597.6563 \\
\hline 2 & 210000 & 840000 & 630000 & 0.610351563 & 384521.4844 \\
\hline 3 & 210000 & 840000 & 630000 & 0.476837158 & 300407.4097 \\
\hline 4 & 106500 & 840000 & 733500 & 0.37252903 & 273250.0434 \\
\hline 5 & 210000 & 840000 & 630000 & 0.291038305 & 183354.1319 \\
\hline \multirow[t]{2}{*}{6} & 210000 & 840000 & 630000 & 0.227373675 & 143245.4155 \\
\hline & & & & NPV & 1072180.829 \\
\hline
\end{tabular}


Table 5. Project C Cash Flows Discounted at 28\%

\begin{tabular}{cccccc}
\hline Years & Cash outflow & Cash inflow & Cash flow & Discounting Factor (1+i) $)^{\wedge}$ n & Present Value(PV) \\
\hline $\mathbf{1}$ & 1212125 & 840000 & -372125 & 0.78125 & -290722.6563 \\
$\mathbf{2}$ & 210000 & 840000 & 630000 & 0.610351563 & 384521.4844 \\
$\mathbf{3}$ & 210000 & 840000 & 630000 & 0.476837158 & 300407.4097 \\
$\mathbf{4}$ & 106500 & 840000 & 733500 & 0.37252903 & 273250.0434 \\
$\mathbf{5}$ & 210000 & 840000 & 630000 & 0.291038305 & 183354.1319 \\
$\mathbf{6}$ & 210000 & 840000 & 630000 & 0.227373675 & 143245.4155 \\
& & & NPV & 994055.8286 \\
\hline
\end{tabular}

Again, subject the three projects to NPV analysis using a discount factor of $32 \%$ reveals a similar trend as the results obtained for the analysis using a discount factor of $28 \%$ as seen in tables 6, 7 and 8 (NPV for A, 598583.07; NPV for B,
945515.0509; NPV for C, 869757.48). Comparing the NPVs for each of the three projects at $32 \%$ discount factor shows that Project $\mathrm{B}$ is the most viable whiles $\mathrm{A}$ is the least viable $(\mathrm{NPV}$ of $\mathrm{B}>\mathrm{C}>\mathrm{A})$.

Table 6. Project A Cash Flows Discounted at 32\%

\begin{tabular}{|c|c|c|c|c|c|}
\hline Years & Cash outflow & Cash inflow & Cash flow & Discounting Factor $(1+i)^{\wedge}-n$ & Present Value (PV) \\
\hline 1 & 662125 & 840000 & 177875 & 0.757575758 & 134753.7879 \\
\hline 2 & 560000 & 840000 & 280000 & 0.573921028 & 160697.888 \\
\hline 3 & 560000 & 840000 & 280000 & 0.434788658 & 121740.8242 \\
\hline 4 & 662125 & 840000 & 177875 & 0.329385347 & 58589.41858 \\
\hline 5 & 560000 & 840000 & 280000 & 0.249534354 & 69869.61904 \\
\hline \multirow[t]{2}{*}{6} & 560000 & 840000 & 280000 & 0.189041177 & 52931.52958 \\
\hline & & & & NPV & 598583.0673 \\
\hline
\end{tabular}

Table 7. Project B Cash Flows Discounted at 32\%

\begin{tabular}{|c|c|c|c|c|c|}
\hline Years & Cash outflow & Cash inflow & Cash flow & Discounting factor $(1+i)^{\wedge}-n$ & Present Value (PV) \\
\hline 1 & 1114400 & 840000 & -274400 & 0.757575758 & -207878.7879 \\
\hline 2 & 210000 & 840000 & 630000 & 0.573921028 & 361570.2479 \\
\hline 3 & 210000 & 840000 & 630000 & 0.434788658 & 273916.8545 \\
\hline 4 & 106500 & 840000 & 733500 & 0.329385347 & 241604.152 \\
\hline 5 & 210000 & 840000 & 630000 & 0.249534354 & 157206.6428 \\
\hline \multirow[t]{2}{*}{6} & 210000 & 840000 & 630000 & 0.189041177 & 119095.9416 \\
\hline & & & & NPV & 945515.0509 \\
\hline
\end{tabular}

Table 8. Project C Cash Flows Discounted at 32\%

\begin{tabular}{|c|c|c|c|c|c|}
\hline Years & Cash outflow & Cash inflow & Cash flow & Discounting factor $(1+i)^{\wedge}-n$ & Present Value (PV) \\
\hline 1 & 1214400 & 840000 & -374400 & 0.757575758 & -283636.3636 \\
\hline 2 & 210000 & 840000 & 630000 & 0.573921028 & 361570.2479 \\
\hline 3 & 210000 & 840000 & 630000 & 0.434788658 & 273916.8545 \\
\hline 4 & 106500 & 840000 & 733500 & 0.329385347 & 241604.152 \\
\hline 5 & 210000 & 840000 & 630000 & 0.249534354 & 157206.6428 \\
\hline \multirow[t]{2}{*}{6} & 210000 & 840000 & 630000 & 0.189041177 & 119095.9416 \\
\hline & & & & NPV & 869757.4752 \\
\hline
\end{tabular}

\section{Conclusion and Recommendations}

It is envisaged that at the end of the project, reviewed syllabus based text books would be developed for each course taught in the Institution to facilitate quality assurance; aid with accreditation and reaccreditation of programmes; generate substantial Internally Generated Fund through books sales to student; serve as promotional materials for staff and source of income. It would also boost the academic 
publishing output of the institution and raise its ranking higher. Appraisal indicates the viability of three projects.

Based on the study, the Project B is recommended, if polytechnics want to go into the production of a syllabusbased textbooks publication. Once these textbooks are published, sales of other materials such as handouts and pamphlets sales to students as course materials must ceased. This can only be enforced if management comes out with a regulation that would stem out this act. Also, there might not be initial fund to cover the printing of all the course materials at a go. This can however be done over a period of three years. The need to come up with new editions to keep up with up-to-date information of all the books published must be emphasized.

\section{References}

[1] Baker, G. (2007). 'Student activism; how students use the scholarly communication system', College and Research Library News, Vol. 68, no. 10 (November). Online at http://www.ala.org/ala/mgrps /divs/acr 1/ publications/crlnews/2007/nov/Student_activism.cfm [accessed 12 January 2009].
[2] Popoola, S.O., \& Haliso, Y. (2009). Use of library information resources and services as predator of teaching effectiveness of social scientists in Nigerian universities. African Journal of Library, Archives and Information Science (AJLAIS), 19(1): 65-77.

[3] Fayose O. (1995). School Library Resources Centre for Educational Excellence. Ibadan: AENI Educational Publishers

[4] INVESTOPEDIA (2013). Net Present Value - NPV. Retrieved from http://www.investopedia.com/terms $/ \mathrm{n} / \mathrm{n}$ pv. asp, [accessed on 17t December, 2013].

[5] Lin, Grier C. I. \& Nagalingam, Sev V. (2000). CIM justification and optimisation. London: Taylor \& Francis.

[6] Oguntuase, F.Z., \& Falaiye, Z.M. (2004). Meeting information needs of ruralcommunities through repackaging of information. Nigerian Library and Information Science Review 22(1): 1-12

[7] Rowlands, I. \& David N. (2008). Information Behaviour of the Researcher of the Future. London: Centre for Publishing for the Faculty of Arts and Humanities, University College London 